\title{
Living in a digital culture: The need for theological reflection
}

Author:

Anita L. Cloete ${ }^{1}$

Affiliation:

${ }^{1}$ Department of Practical Theology and Missiology, University of Stellenbosch, South Africa

Note:

This article is published in the section Practical Theology of the Society for Practical Theology in South Africa.

Correspondence to:

Anita Cloete

Email:

acloete@sun.ac.za

Postal address:

Private Bag X1, Matieland

7602, Stellenbosch, South

Africa

Dates:

Received: 21 Sept. 2013

Accepted: 29 Mar. 2014

Published: 11 Feb. 2015

How to cite this article: Cloete A.L., 2015, 'Living in a digital culture: The need for theological reflection', HTS Teologiese Studies/ Theological Studies 71(2), Art. \#2073, 7 pages. http://dx.doi.org/10.4102/ hts.v71i2.2073

\section{Copyright:}

(C) 2015. The Authors. Licensee: AOSIS

OpenJournals. This work is licensed under the Creative Commons Attribution License.

\section{Read online:}

Scan this $Q R$ code with your smart phone or mobile device to read online.
Today our lives are filled with technology through which we communicate, work, play and even engage with for making meaning. This implies the pervasive presence of digital media as an integral part of our everyday life. Although studies on media are mostly done by sociology and communication students, living in a digital age has significant implications for theological reflections. Despite this being the case there is gap in terms of a religious response to technology. In response to this, the aim of this article is to stimulate theological reflections with regard to living in a digital culture. This is achieved by raising theological questions in the hope that theology could take a proactive role in these discussions. The implications of living in a digital culture are quite vast; therefore, the focus will be limited to how a community is formed and sustained, and the possible implications for the church as community.

\section{Introduction}

The aim of this article is to address the gap that currently exists with regard to a religious response to the use of technology; for example, a website containing the basic information about congregations or a Facebook page where congregants and other interest groups can interact with each other (Graham 2009:222; Padgett 2005:577). Soukup, Buckley and Robinson (2001:368) summarise the relationship between technology and religion as follows: 'The world that people inhabit affects them - their religious outlook, the questions they judge important, and their religious practice. Obviously theology shares in this'. In order to provide a backdrop for the discussion on the need for theological reflection with specific reference to community, the first section provides an overview of what is meant by the digital age. This is done by highlighting the main characteristics of digital culture and providing a short outline of four theoretical and three theological perspectives on digital culture. In an effort to explain community formation today, online church communities, the availability of religious information and related issues like authority will be discussed. The implications of mediated religion and the mediatisation of religion will also be considered.

I have made certain assumptions in relation to technology and humanity, and its implications for theology. Firstly, digital technology consists of more than just artefacts or technological objects that are used for information gathering purposes as it affects us on an existential level. The availability of advanced technology is therefore reshaping what it means to be human (Punt 2013:8; Van den Berg 2012:2 of 6). Furthermore, technology is more than the embodiment and systematisation of information - it also constitutes a body of knowledge. Information on any topic can be found on the Internet and because of the interactive nature of the hypertext, related links will guide the searcher to find much more on a specific topic. It could further be argued that technology has its own set of values and is transforming the very nature of being human as it impacts the way we think about ourselves. Technology is no longer a luxury, but forms part of what is needed for survival (Graham 2009:222). Technologies are also vehicles of transformation of both the world around us and of our own becoming (Graham 2009:227). Although technology could be viewed as secular, it could at the same time create sacred spaces (Padgett 2005:579).

\section{The digital age}

The digital age could be described as the current context wherein digital media are present in all spheres of lives. Digital media have certain characteristics that are noteworthy to indicate how it influences human beings and their existence, as well as the social context. The characteristics of the digital age can be considered as 'networked' via different forms of media like telephones and the Internet. Digital media are also interactive in terms of its responsiveness between the user and the media object. The different media forms are composed of nodes and blocks which are connected by different links between them, which make the text hypertextual (Miller 2011:17). 
Closely linked to the characteristic of hypertextuality is the fact that digital media are databased, which refers to a structured collection of data. The fact that digital media can be easily manipulated and modified by people is described by Miller (2011:19) as automation and regarded as one of the key components of digital media. The automation and interactiveness of digital technology imply that people do not only use technology but are cocreators thereof when using it. The fact that it is hyperlinked means that people can spend a significant amount of time on the Internet, jumping from one link to another; users could potentially be overwhelmed with the available 'new' information. Living in a digital culture does not only imply unfamiliar forms of communication or sources of information, but raises important questions in terms of our existence and relationships, such as 'How can we be absent yet also present?' and 'What is the self if it is not in a body?' In other words, 'Where and who is the real self in digital communication?' and 'Was there ever a real self?' Due to the fact that we are present and absent at the same time when using the digital media, the self becomes problematic. This phenomenon in online relationships is referred to as 'connected presence' which means we are continuously contactable no matter our physical presence (Miller 2011:203).

What if there is a contradiction between the online and offline self? It could be argued that the borders between human and machine collapse and the self and the body are thrown into flux (Baym 2010:3). The boundaries between personal and mass communication are also blurred to the point that they become disruptive for both (Baym 2010:4). For Baym (2010:5), at the heart of this boundary flux lays the question: 'What is real and what is considered virtual?' Baym (2010:5) articulates the challenge associated with this question as follows: 'Digital media calls into question the very authenticity of our identities and relationships and practice'. What needs to be highlighted is the fact that digital living is marked by new forms of communication. This implies that new worlds are created as digital platforms and become the primary location of communications and symbolic connections. Communication could also be viewed as a ritual whereby people construe and construct their world (Soukup et al. 2001:370).

\section{Theoretical perspectives on digital culture}

It seems important to have some theoretical tools to engage with digital culture and to determine how it is intertwined with our existence. I would like to introduce four theoretical perspectives that could be used to make sense of digital media and its effect on humanity. According to a determinism perspective, technology arises independently from a social context, but then affects this context. The opposite view is that of social construction of technology, according to which technologies arise from social processes and therefore inventors of technology are embedded in the social context. A social constructivist perspective thus postulates that there are many factors that influence technology development beyond the inventors. A third perspective, social shaping, seems to provide a more balanced view on engaging with digital media as it acknowledges both the effect of technology as well as the participation of people that invent and use them. Social shaping could therefore be viewed as a combination of both the determinism and constructivist approaches (Wessels 2010:31-33). Baym (2010:23) concludes that our reflections on technology say as much of the technology as it is does about us and our societies.

Hjarvard (2011:121) recognised these perspectives as the first and oldest paradigms concerning digital media, but introduces mediatisation as a newer paradigm in this regard. This perspective is of importance as mediatisation goes beyond a simple causal logic by stressing the interaction between actors and structures. This implies that media is seen as part of society and therefore at work in all types of institutions (Hjarvard 2011:121). According to the mediatisation paradigm, the media has developed into an autonomous independent institution in society and is at the same time being integrated into the workings of other social institutions. The independence and autonomy of digital media imply that it is no longer in service of other institutions, but now has a logic of its own to which social institutions have to adhere. The media is not a unified phenomenon and therefore media logic is not a singular, uniform logic, but refers to the institutional, aesthetic technological modus operandi of the media. Mediation could be viewed as part of mediatisation, but it is not the same. Whilst mediation refers to the concrete act of communication via a medium, mediatisation refers to the institutional perspective (Hjarvard 2011:122-123). For the purpose of this article it is important to indicate what theological perspectives exist in relation to digital media.

\section{Theology and technology}

Garner (2013:253-255; cf. Graham 2009:225) highlights three theological views on technology. The first perspective sees technology as liberator. This is an optimistic response that sees technology as liberating force that has the potential to contribute to overcoming the world's greatest challenges like hunger and poverty in order to improve the human condition. According to this view, digital technology provides the church with more tools and opportunities to reach more people with the gospel and is therefore seen as having a positive influence on church activities and institutional structures.

The second view could be seen as the opposite of the previous perspective as technology is seen as oppressor. Therefore, it could be regarded as a pessimistic view where technology is seen as a threat to what is truly human. The pervasive nature of technology is regarded as negative and could potentially cause a breakdown in terms of face-to-face relationships. The availability of pornography (especially to children) is also seen as a significant ethical and moral concern.

Lastly technology is seen as an instrument representing a view that is situated in the middle of the other two. This view describes the ambiguous power of the digital media and it is seen as value neutral until it is applied and the consequences of the application indicate whether it was used 
positively or negatively. This view acknowledges that digital media is not created and used in a vacuum, but is rather a social construction and when used, is guided by social and institutional values. This view celebrates creativity, but at the same time is suspicious of human power. From the theoretical and theological perspectives on engaging with technology, it is clear that technology is created by human beings, and affects human beings on an existential level.

Therefore, theological reflection on technology is of great importance because it acknowledges that technology is more than just artefacts; it embraces human beings, their relationships and the values according to which they live. According to Garner (2013:256), theological reflections on technology have at least two overlapping directions, namely what it means to be part of a church in a digital age and what the implications are of digital media for the wider society.

\section{Living in a digital culture: Areas for theological reflection}

The creation of technology and the use thereof imply certain values which also constitute a rich field for theological reflection. In other words, to what extent do values play a role in the creation and use of different digital media forms? The digital media should not be viewed as merely tools to use in church because they constitute a way of living - a digital culture. Digital media are more than a medium to deliver a message and, as a result, we need a new metaphor that conceives media as an environment, a context, a culture (Medrano 2004:147-148).

Another area for research is spiritual formation in a digital age. The digital media is viewed as one of the primary sources of popular culture through films, advertisements, music, the latest gadgets, et cetera. Popular culture often fills the spiritual gap as it becomes a way of engaging with the spiritual inclination of specifically the youth. Three aspects that are frequently discussed in media studies with regard to a digital culture - namely identity, community and religion - are also integral elements of spiritual formation (Cloete 2012) which can therefore also be identified as an area for theological reflection (cf. Van den Berg 2012). The field of religion in Internet studies definitely needs more scholarly attention as it seems to have tremendous implications; for example, the training of religious leaders of specifically offline or traditional congregations. Does the training of theological students make room for the focus on life in a digital culture which implies that congregants could find religion information online (i.e. religion online) or even participate in religious practices online (i.e. online religion). Does theological training prepare students on how to deal with this as a leader of an offline religious community? Religious leadership when living in a digital culture therefore constitutes an area for theological reflection.

The final section of this article will focus specifically on how community is formed and sustained in a digital culture and the implications thereof for the church as community today.

\section{Community in a digital culture}

Although the concept 'community' is well-known and widely applied, there is no consensus on what it exactly means (Campbell 2013:59; Miller 2011:184). However, community is a very useful concept that indicates some close connections or social bonds between people (Baym 2010:74). Digital technological platforms are filled with language that suggests a sense of community; for example, on Facebook one could become friends with others and share day-today experiences whilst on LinkedIn you could become part of different professional networks (Joubert 2010:52). Therefore, Joubert (2010) proposes that one of the heuristic keys to engage with living in a digital culture is the need for connectivity, which refers to the use of different digital technologies for divergent needs and how that connects people. In a digital age, community is constructed out of communication based on personal choice and between individuals. According to the traditional understanding of community (Wessels 2010:49), the community that is formed is described as belonging to individuals rather than individuals belonging to a community. These individualised online connections are further described as displacing communities with networks as people belong to different networks based on individual interest and choice (Miller 2011:197; Wessels 2010:53). This individualised nature of online community through different networks is described as 'networked individualism' in which each person sits at the centre of his or her own personal community (Baym 2010:90). Miller (2011:199) emphasises networked individualism and refers to the work of Wellman (2002), amongst others, in this regard. Networked individualism is closely linked to what Miller (2011:191) calls the freedom of engagement, increased mobility, choice and specialised relationships that characterise online communities (Miller 2011:199). Relationships that are formed through online communities are therefore more person-centred and need-centred than place-centred. It further means that each individual has his or her own personal community, which also constitutes a shift in the nature of community (Hutchings 2011:1131). Community therefore hinges on individualised networks.

Another important characteristic of online networks is that it is flexible and does not mean that people share the same geographical space. This phenomenon is described by Giddens (1991) as the disembedding of social relationships and organisations. Disembedded relationships allude to the fact that relationships take place in a context where time and space are separated and the interaction is governed by abstract systems. Therefore, online communities could be viewed as people that share the same cyberspace by using different media platforms such as Facebook, Twitter and LinkedIn, but not the same geographical space. Digital media offer opportunities to form relationships with a wide and diverse range of people without being bound by geographical space. Online communities therefore transcend geographical and physical space and form a new shared space via digital media. Although these online communities could be used to 
maintain existing relationships, it is definitely used to form new social bonds. Online communities are used for different needs; for example, LinkedIn users share professional information whilst Facebook is mostly used to share day-today experiences and could therefore also provide a source of support. Baym (2010:83-86) identified three sources of support that online communities offer, namely emotional, esteem and informational support. According to what needs are met, Miller (2011:190) describes online communities as communities of transaction, interest, fantasy and relationships. Individualised network communities are thus formed on the basis of personal choice and need. It could therefore be described as instrumental network communities.

At the heart of community lie relationships, and the question that is frequently asked is whether these virtual communities could be seen as valid, real and authentic. A closer look at what is meant by online communities might be of help in formulating a response to this question. Online communities represent social spaces where people still meet face-to-face but with a new or different understanding of what it means to 'meet' and 'face' someone. Online community implies more than just sharing information and interests, but also includes emotional investment. Although the platform of interaction has changed, online communities still entail the basic act of social exchange (Campbell 2013:59). Joubert (2010:52) notes that the virtual world is real especially for the 'Net Geners'. The 'Net Geners' are the generations that grew up within the digital world and do not know any other world than the one filled with digital media and technology. Joubert (2010:50) refers to Estes's book entitled SimChurch: Being church in the virtual world (2009) where the question surrounding the nature of 'virtual' and 'real' is also discussed. Estes's response is that 'a virtual world is a created space where people can interact as if in the real world, but through some kind of technological medium'. The virtual or online community is therefore not fictional as a fictional world is a mode of possibility whereas the virtual world is a mode of reality. In the same vein, Campbell (2013:63) notes that research increasingly points to the fact that there is greater integration with regard to online and offline communities despite the fact that online communities are often viewed as inauthentic and unreal. Campbell (2013) concludes that online and offline communities should rather be viewed as complementary and an extension of each other rather than being in competition or mutually excluding. In other words, it could be argued that if offline communities are seen as real, online communities could not be viewed differently.

Online communities are not only used to share common interests or information but are also places where people seek religious information and practice religion. This reality leads to concepts like 'digital religion', 'online religion' and 'religion online'. Although the two terms 'religion online' and 'online religion' seem similar in nature, there is a difference as the first refers to the variety of religious information that is available on the Internet, whilst the latter refers to religious practices that are performed online. Religion online thus provides information about religion and online religion the opportunity to participate in religious activity (Young 2004:93). Religion online presents one-way communication whilst online religion is characterised by reciprocity (Young 2004:95). Digital religion, on the other hand, is 'religion that is constituted in new ways through digital media and cultures' (Campbell 2013:3). Campbell (2013:4) describes digital religion further as a technological space where online and offline religion become mixed and blended spheres, which is in line with her understanding of online and offline communities as complementary and integrated. Digital religion thus includes both religion online and online religion.

Hutchings (2011:1118) describes Internet-based Christian communities or 'online churches' as loosely networked religious practices, which blend offline and online resources and practices. According to the view of continuity and complementarity, offline religious communities are reframed, shaped and sustained by online practices (Cheong 2013:78). An opposite view is that online communities displace and even replace offline communities. Cheong (2013:83) reports on an added logic of complementarity that includes transmediation whereby authority practices are remediated across different communication platforms. These different views on the relationship between online and offline communities point to the different effect the media could have in a different context, as well as to the paradox of engaging with the media. To illustrate the point on the paradoxical effect of the media, Chados (2012:264) argues that digital technology led to the loss of mystery. At the same time, according to mediatisation theory (Hjarvard 2011), the media can use nonreligious symbols to create spiritual experience and mystery. Hutchings (2011:1128-1129) has an interesting way of describing the complex and mutually constructive relationship between online and offline church communities as operating along two axes, namely familiarity and difference as well as integration and isolation. The axis between familiarity and difference speaks to the fact that online churches reproduce the forms and structures of offline churches, but also appropriate the unique features of the digital media. Online churches therefore do not simply reproduce the familiar, but is also shaped according to the affordances of the digital media. It is precisely the negotiation between the familiarity and difference that generates appeal to the users. The second axis runs between integration and isolation which means that digital media can become part of everyday life or be kept separate from it by intentional individual practice (Hutchings 2011:1130). In the light of the discussion on how online and offline communities are formed and how they are related, the final sections will focus on the implications thereof for the church as community.

\section{Possible implications for the church as community in a digital culture}

The church is often referred to and experienced as a community of care, worship, and even as an alternative community. Dawson (2004:75) writes that 'in popular mind religion and community go hand in hand'. In the light of the 
foregoing discussion, I would like to point out a few areas that are in need of theological reflection specifically with regard to the church as community in a digital age. Campbell (2013:61) refers to the online religious community as the congregation of the disembodied'. What does this mean for a theology where the 'incarnation' and 'becoming flesh' are core elements? It is important to note that these elements refer to the same thing, just worded differently; it is better to have bodily presence as part of embodiment as this has been taken for granted in offline religious communities as well as in Christian theology. According to Ostrowski (2006:7), 'there is a concern in Christianity that the physical presence of other worshippers is necessary'. What constitutes embodiment in a digital age that is characterised by bodily absence? Cilliers (2012) notes that:

$[T]$ he network culture again invites us to rethink and revisit our notions of embodiment. Should we accept that participants in the network society tend to 'float' in 'virtual reality', i.e. that they have no responsibilities for the present, no guilt in terms of the past and no anticipation for the future. (p. 49)

Despite these concerns, Helland (2004:31) describes online religion as an acceptable space for spiritual and religious participation where there is no hierarchical segregation and where church members, as well as those who left the church, can be part of an ongoing religious dialogue. Online religion could be seen as a medium of nondenominational, non-affiliated religious participation and as an open religious environment that caters for people who want to be religious and spiritual on their own terms (Helland 2004:33-34). This could imply that in a digital age there is much believing without belonging in the traditional sense.

If religious online communities are also formed through individual choice, it could lead to homogeneous groups with the same theological viewpoints. Online religion also has the potential to perpetuate offline fundamentalist theological views of fundamentalist communities that, for example, still see women lesser or inferior to men and chooses to understand the Bible exclusively from a patriarchal perspective. At the same time, online religion could create a space for people to voice alternative theological views that do not fit the offline religious community. Current studies by Huchings (2011) and Teusner (2010) support both perspectives, namely that online religious communities deliberately replicate familiar offline everyday activities. On the other hand, members may use their online activities consciously to resist traditional forms of community and to form a more fluid religious identity that allows them to experiment with new ways of religious interactions online (Campbell 2013:67). This fluid nature in online communities is very important as an individual does not have to be restricted to a particular environment, but can choose to leave or stay on his or her own terms. At the same time, it could have implications for commitment and participation which is often valued in offline religious communities. This kind of community does not foster mutual responsibility and interdependency (Miller 2011:19). Relationships in online communities could be viewed as purely instrumental because people engage mainly for what they can get out of it and not primarily to share responsibility for each other, which is in sharp contrast to why and how offline communities are formed. The individualised and self-serving nature of online communities could be viewed as in sharp contrast with the nature of the church as community that is in service of the world and does not exist for itself.

Religion online, on the other hand, has some interesting implications as it implies that religious and theological information from a variety of sources is available online. This means that the traditional structure of the church as the primary source for religious and theological information and authority is bypassed. The same applies for authentic figures like pastors that were seen as authorities in a previous age with regard to religious and theological information. Cheong (2013:75) summarises this challenge as follows: 'The Internet challenges authority by expanding access to religious information in a way that undermines the plausibility structure of a religious system'. It is therefore important to have a closer look at what mediated religion entails. The fact that the media became an important source for religious information and to engage with it for spiritual experience refers to the agenda-setting function of the media. Part of how the media decides on what to report on and how to report on it is by filtering information (Soukup et al. 2001:368).

The agenda-setting function of the media implies that it acquires some of the church's former power to define and frame religious issues (Hjarvard 2011:125-126). Alongside the agenda-setting function and power of the media is the reality that the media in general is not interested in propagating a specific religious view, but on the contrary, use existing institutionalised religious material for its own purpose (Hjarvard 2011:126). This characteristic of the media is called banal religion (Hjarvard 2011:128), according to which the media may take existing institutionalised symbols without the intension of conveying a specific religious message or, on the other hand, incorporating nonreligious symbols that could be associated with religious meaning through the media's representational practices. The Bible as sacred text is used more in the media today than before. Punt (2013:1) describes this tendency as popularising the Bible in the media and refers to the 'pop-bible'. The pop-bible could give a possible platform for discussion; however, it could also represent a shallow and even twisted interpretation of the sacred texts (Punt 2013:3-5). The mediatisation of religion seems to be important for both religion online and online religion. Therefore, I would like to summarise the implications thereof for religion as follows (Hjarvard 2011:124):

- The media has become an important, if not primary, source on religious issues.

- Religious experience and information are moulded according to the demands of popular genres.

- Media takes over many of the functions of institutionalised religion by giving spiritual guidance and moral orientation. 


\section{Conclusion}

The first aim of the article was to give a concise overview of what it means to live in a digital culture. In the light of the characteristics of digital technology, four theoretical and three theological perspectives were highlighted. It becomes clear that digital technologies are more than tools or technological inventions; these technologies are closely related to who we are as humans, how we live our lives, and what choices we make in the midst of several options provided by the digital media. The interactions between humans and technology provide a significant site for theological reflection. Therefore, the second aim is to raise theological questions in connection with living in a digital age in order for theology to play an active role in discussions on digital media and humanity. Several areas of theological reflections were indicated, namely spiritual formation, ethical decision-making, theological training and religious leadership. The last aim was to focus on community formation in a digital age and the implications thereof for church as a community. The following conclusions are made in this regard.

Although there seems to be many ways religion could benefit from the use of digital technologies, it could also be seen as religion's worst nightmare (Helland 2004:30). I would like to suggest that online and offline communities should be seen in tandem as research from Campbell (2013) increasingly shows that online and offline communities constitute people's way of living today. At the same time, paradox seems to be a helpful way to engage with how living in a digital culture affects who we are (identity) and how community is formed. Although it is a valid argument that online relationships and communities erode and interrupt offline relationships, it provides multiple platforms to sustain current relationships and build new ones with a wide and diverse audience at the same time. Regardless of the fact that a broad body of research points to a greater integration of offline and online communities, I am of the opinion that the two could not be viewed as identical. Online communities are characterised by mediated communication through digital technologies and the absence of the body, whilst in offline or traditional communities' communication is not mediated by digital technologies but by physical bodily presence. Furthermore, online communities are formed on the grounds of our own choice and needs, whilst offline communities are formed not so much by choice, but by sharing the same geographical space. Networked individuality, whereby an individual's choice of whom they choose to connect with is central to the formation of online communities, could lead to homogeneous communities; however, at the same time, it grants access to a diverse cohort of people. These individualised network communities that imply community belong to individuals and could be viewed as self-serving as is often understood as the mission and mandate of the church. What embodiment means within a digital culture seems to be one of the most important areas in need of theological reflection. Embodiment is more than physicality, but from a theological perspective the body is also the address of revelation: 'It is the prime locus of God's presence with us' (Cilliers 2009:52). It could also be said that Christ exists in the form of the congregation (Cilliers 2009:53). Therefore, both the human body and the church as body need to be reflected upon as both are affected in a digital age. Online and offline communities could be viewed as two worlds we are living in simultaneously, which could cause tension for both worlds.

The mediatisation of religion entails much more than religious information via digital media, but also includes the use and misuse, if you like, of religion for its own purpose. Furthermore, it points to the fact that the church as institution has to adapt to the media logic in order to communicate effectively with society. The strong point of mediatised religion - not to preach a particular religion, but to be open to a pluralised worldview - is exactly also its weak point as it destabilises religious authority (Hjarvard 2011:133). Hjarvard (2011:131) argues that the availability of more religious information should not to be equated with growing support for involvement with religion, as digital media has the potential to destabilise and/or establish religion. Therefore, Hjarvard (2011:130-133) asserts in his final analysis of the mediatisation theory that it tends to be intertwined with the process of secularisation. I would like to echo Graham's (2009:235) call for a dialogical relationship between theology and technology of mutual critique. In this dialogical relationship, the Christian faith particularly has the ability to provide a counterculture with an alternative vision for humanity beyond the destructive nature of the totalising technological worldview (Padgett 2005:582). At the same time, theology could assist us in understanding how God is at work in and through technology by recognising human creativity as an integral part of the digital age. This new kind of togetherness whilst we are alone created by online communities provides interesting areas for interdisciplinary research from which theology dare not be absent.

\section{Acknowledgements Competing interests}

The author declares that she has no financial or personal relationship(s) that may have inappropriately influenced her in writing this article.

\section{References}

Baym, N.K., 2010, Personal connections in the digital age, Polity Press, Cambridge.

Campbell, H.A., 2013, 'Community', in H.A. Campbell (ed.), Digital religion: Understanding religious practice in new media worlds, pp. 3-67, Routledge, Abingdon.

Chados, R., 2012, 'Reflections on the impact of "the digital revolution" on art and religion', Crosscurrents 62(2), 260-269. http://dx.doi.org/10.1111/j.19393881.2012.00233.x

Cheong, P.H., 2013, 'Authority', in H.A. Campbell (ed.), Digital religion: Understanding religious practice in new media worlds, pp. 3-67, Routledge, Abingdon.

Cilliers, J., 2009, 'Fides quaerens corporalitatem: Perspectives on liturgical embodiment', Verbum et Ecclesia 30(1), 52-53. http://dx.doi.org/10.4102/ ve.v30i1.63

Cilliers, J., 2012, 'Timeless time and placeless space? Theological-liturgical perspectives on the notion of liminality in the network culture', Questions Liturgiques: Studies in Liturgy 93(1/2), 34-50.

Cloete, A., 2012, 'Spiritual formation as focus of youth ministry', Nederduitse Gereformeerde Teologiese Tydskrif 53(3/4), 70-77.

Dawson, L.L., 2004, 'Religion and the quest for virtual community', in L.L. Dawson $\&$ D.E. Cowan (eds.), Religion online: Finding faith on the Internet, pp. 75-89, Routledge, London. 
Estes, D., 2009, SimChurch: Being church in the virtual world, Zondervan, Grand Rapids, MI.

Garner, S., 2013, 'Theology and the new media', in H.A. Campbell (ed.), Digital religion: Understanding religious practice in new media worlds, pp. 253-256, Routledge, Abingdon.

Giddens, A., 1991, Modernity and self-identity: Self and society in the late modern age, Polity, Cambridge.

Graham, E., 2009, 'Being, making and imagining: Towards a practical theology of technology', Culture and Religion: An Interdisciplinary Journal 10(2), 221-236. http://dx.doi.org/10.1080/14755610903077588

Helland, C., 2004, 'Popular religion and the World Wide Web: A match made in cyber Heaven', in L.L. Dawson \& D.E. Cowan (eds.), Religion online: Finding faith on the Internet, pp. 30-34, Routledge, London.

Hjarvard, S., 2011, 'The mediatisation of religion: Theorising religion, media and social change', Culture and Religion: An Interdisciplinary Journal 12(2), 119-135. http:// dx.doi.org/10.1080/14755610.2011.579719

Huchings, T., 2011, 'Creating church online a case-study approach to religious experience', Studies in World Christianity 13(3), 1118-1131. http://dx.doi. org/10.3366/swc.2007.13.3.243

Joubert, S.J., 2010, 'Annus virualis: Enkele uitdagings wat die virtuele era van Web 2.0 aan relevante kerklike bedieninge stel', Nederduitse Gereformeerde Teologiese Tydskrif 51(3/4), 48-60.

Medrano, A.M., 2004, 'Making religious media: Notes from the field', in P. Horsfield, M.E. Hess \& A.M. Medrano (eds.), Belief in media: Cultural perspectives on media and Christianity, pp. 147-148, Ashgate, Burlington.
Miller, V., 2011, Understanding digital culture, Sage Publications, Thousand Oaks.

Ostrowski, A., 2006, 'Cyber communication: Finding God in the little box', Journal of Religion \& Society 8, 1-7.

Padgett, A.G., 2005, 'God versus technology? Science, secularity, and the theology of technology', Zygon 40(3), 577-584. http://dx.doi.org/10.1111/j.14679744.2005.00689.x

Punt, J., 2013, 'Die pop-Bybel vandag', Nederduitse Gereformeerde Teologiese Tydskrif $54(1 / 2), 1-12$

Soukup, P.A., Buckley. F.J. \& Robinson, D.C., 2001, 'The influence of information technologies on theology', Theological Studies 62, 366-377. http://dx.doi. org/10.1177/004056390106200207

Teusner, P., 2010, 'Emerging church bloggers in Australia: Prophets, priests and rulers in God's virtual world', PhD thesis, Dept of Media and Communication, RMIT University.

Van den Berg, J.A., 2012, 'Theoretical signposts for tracing spirituality within the fluid decision-making of a mobile virtual reality', HTS Teologiese Studies/Theological Studies 68(2), 1-6. http://dx.doi.org/10.4102/hts.v68i2.1290

Wellman, B., 2002, 'Little boxes, glocalization and networked individualism', in M. Tanabe, P. van den Besselaar \& T. Ishida (eds.), Digital cities 11. Computationa and sociological approaches, pp. 10-25, Springer-Verlag, Berlin. http://dx.doi. org/10.1007/3-540-45636-8_2

Wessels, B., 2010, Understanding the Internet: A socio-cultural perspective, Palgrave MacMillan, New York, NY.

Young, G., 2004, 'Reading and praying online: The continuity of religion online and online religion in Internet Christianity', in L.L. Dawson \& D.E. Cowan (eds.), Religion online: Finding faith on the Internet, pp. 93-95, Routledge, London. 